\title{
THE 2002 BALI BOMBING AND THE NEW PUBLIC SPHERE: The Portrayal of Terrorism in Indonesian Online Discussion Forums
}

\section{Yuyun Sunesti}

Sunan Kalijaga State Islamic University (UIN) Yogyakarta

yuyunsunesti@gmail.com

\section{Abstract}

This article examines heroic conceptions of terrorists, support, and sympatby for terrorism in Indonesia by undertaking a content analysis of four Indonesian online discussion forums in the aftermath of the 2002 Bali bombing. It is argued that online discussion forums are a particularly appropriate source of data from which to analyse Indonesians' perceptions of the bombers, as these forums are widely thought to be representative of a new public sphere that allows forpolitical debate and participation. From discussions between July 2008 and January 2009, the article outlines how the bombers were constructed as heroes and anti-heroes by different members of different forums. Drawing on a cultural sociological perspective, the article highlights the importance of understanding the reputation of individual terrorists, and the influence of established heroic types in understanding contemporary conflict in Indonesian society.

[Artikel ini membahas konsepsi kepablawanan teroris, dukungan, dan simpati terbadap terorisme di Indonesia dengan melakukan analisis isi terbadap forum diskusi online terkait dengan peristiwa Bom Bali tabun 2002. Diasumsikan babwa forum diskusi online merupakan sumber yang memadai untuk melihat persepsi masyarakat Indonesia mengenai pelaku pengeboman, karena forum seperti ini cukup dipercaya sebagai perwakilan ruang publik baru memungkinkan terjadinya keterlibatan dan debat yang bersifat politik. Dari diskusiyang terjadi antara Juli 2008 sampai Januari 2009, tergambar dalam artikel ini babwa para pelaku pengeboman dikonstruksikan sebagai seorang pablawan sekaligus sebagai musuh dalam forum yang berbeda. Dengan 
Yuyun Sunesti

perspektif sosial-budaya, tulisan ini menggaris-bawahi pentingnya pemahaman terhadap reputasi masing-masing teroris dan pengaruh tipologi kepablawanan dalam memahami konflik di tengah masyarakat Indonesia saat ini.]

Keywords: Bali Bomb, online forum discussion, public sphere, terrorism.

\section{A. Introduction}

The Bali bombings were a shocking tragedy for Indonesia and the various Western countries that suffered casualties. The bombings were carried out on 12 October 2002, approximately one year after the tragedy of $9 / 11$ in the United States and resulted in approximately 202 deaths (including 88 Australians and 38 Indonesians), 325 people injured and 422 buildings destroyed, as well as damage to many public facilities. ${ }^{1}$ The bombings also negatively affected economic development in Indonesia, in particular through crippling tourism industry.

This tragedy was also a psychological shock for both Indonesia and the rest of the world. Azra called it "a new phase of violence and terror in the country", in terms of the number of victims, the explosive material used and the use of the suicide bomber. ${ }^{2}$ After the bombing, twelve suspects were arrested and three were charged with the death penalty including Amrozi, Imam Samudra and Ali Gufron. After their executions were delayed several times, on 9 November 2008, they were executed on Nirbaya hill in Cilacap, Central Java, by firing squad.

Along with the perpetrators' executions, debates have raged among Indonesians about their legacy as martyrs or criminals. The idea of their heroism was thought to come from those who perceived their acts as jihad against the infidel America and its allies, while the condemnation came up as a response to their cruelty of killing for a religious reason. This could be seen in demonstrations, and in debates in radio, television and newspapers, which intensively occurred during the period of their executions. However, the extent and precise nature of the debate on the surface is difficult to know as Indonesian newspapers and television

${ }^{1}$ Muhammad Asfar (ed.), Islam Lunak Islam Radikal: Pesantren, Terrorisme dan Bom Bali (Surabaya: PuSDeHAM dan JP Press, 2003), p. 79.

${ }^{2}$ Azyumardi Azra, "Bali and Southeast Asian Islam: Debunking the Myths", in After Bali: The Threat of Terrorism in Southeast Asia, ed. by Kumar Ramakrishna and Seng Seng Tan (Singapore: Institute of Defence and Strategic Studies, Nanyang Technological University and World Scientific Publishing Company, 2003), p. 52. 
stations are subject to censorship and control by government and powerful media ownership. By contrast, this paper considers the attitudes of Indonesians through examining internet discussions. The internet allows people to easily and freely discuss current political issues without revealing their identities. Online discussion forums have become one form of mediated communication in which critical debate as well as flowing conversation can be easily found. In contrast, mainstream media is restricted to a limited number of professional writers or contributors. In Indonesia, online discussion forums have been a hub for debates about terrorism in Indonesia, especially the Bali bombing and the heroism of the perpetrators.

It is the purpose of this paper to examine how Indonesian people view terrorist acts in Indonesia by using the 2002 Bali bombing as a case study. Since the discussions were mostly focused on the debate of the perpetrators' heroism, this article will address the question: To what extent does this event appear in Indonesian online discussion and what is the basis of the arguments for characterising the bombers? The answer is important to understand because it tests assumptions regarding heroes in Indonesia which then become debated when applied to terrorist figures. Here, I use online discussion forums, theorizing them as a part of a new public sphere in which people's opinions are can be freely expressed and debated. The findings of this article inform sociological understandings of the rise of democracy in Indonesia in terms of the public sphere and highlight the need to better understand the new and unique anomaly of the hero that is rarely imagined and discussed in Asia.

\section{B. Terrorism and the Online Public Sphere}

Terrorism is a word referring to an indiscriminate evil, violence or brutality. ${ }^{3}$ Labelling a group or action as terrorist is suggesting they commit acts which are immoral, wrong or contrary to common values. ${ }^{4}$ Terrorism can also be used to describe violence by an organization to threaten or frighten a target audience, which is generally for gaining two purposes; gaining supporters and coercing opponents. ${ }^{5}$ Lutz and Lutz highlighted that political purposes and motives are usually involved in

${ }^{3}$ James M. Lutz and Brenda J. Lutz, Global Terrorism (New York: Routledge, 2004), p. 8.

${ }^{4}$ Ibid.

${ }^{5}$ Robert Anthony Pape, Dying to Win: the Strategic Logic of Suicide Terrorism (New York: Random House, 2005), p. 9. 


\section{Yuyun Sunesti}

many terrorist actions. ${ }^{6}$

Southeast Asia has been one of the concerns of the discussion of terrorism due to the increase of the terrorism events in this region. Sukma, Hasan, Yunanto and Barton argued that the terrorism that exists in Southeast Asia in general and in Indonesia in particular is part of a global jihad linked to Al-Qaida and Jamaah Islamiah. ${ }^{7}$ However, besides this transnational terrorism, Abuza and Sukma also relate the rise of terrorism in Indonesia with the growth of radical Islam, which was a result of authoritarianism in the new order era and then as a product of the disordered democratic transition. ${ }^{8}$ Abuza mentioned that this can be seen in the form of the demand for the implementation of Islamic sharia as well as the perceptions built by Islamists, militants and terrorists that Islam is under attack and the war on terrorism means anti-Muslim. ${ }^{9}$

Started by Imam Samudra's justification of the bombers actions in the 2002 Bali bombing, the debate about terrorism and martyrdom in Indonesia was established. Samudra argued that their 2002 Bali bombing was jihad against America and its allies as revenge for their cruelty in Afghanistan, Iraq and other Islamic countries. For this jihad, he stated that they were ready for the death penalty with an eternal life as martyrs as the reward. ${ }^{10}$ Several studies have been written with the view that what Samudra did and argued for was against humanitarian values. Hasan, Baabduh, Abas and Hassan viewed that Imam Samudra's justification of the Bali bombing in his book is unreasonable, totally wrong, deviant and spoiling Islam. They also questioned what Samudra call jihad as contrary

\section{${ }^{6}$ Lutz and Lutz, Global Terrorism.}

${ }^{7}$ Rizal Sukma, "Indonesia and The Challenge of Radical Islam After 12 October", in After Bali: the Threat of Terrorism in Southeast Asia (Singapore: Institute of Defence and Strategic Studies, Nanyang Technological University and World Scientific Publishing Company, 2003), p. 350; Noorhaidi Hasan, "September 11 and Islamic Militancy in Post-New Order Indonesia", in Islam in Southeast Asia: Political, Social and Strategic Challenges for the 21st Century, ed. by K.S. Nathan and Mohammad Hashim Kamali (Singapore: Institute of Southeast Asian Studies, 2005), pp. 301-21; S. Yunanto, Militant Islamic Movements in Indonesia and South-East Asia Jakarta: Friedrich Ebert Stiftung, 2003); Greg Fealy, Indonesia's Struggle: Jemaah Islamiyah and the Soul of Islam (Sydney: UNSW Press, 2004).

${ }^{8}$ Zachary Abuza, Political Islam and Violence in Indonesia (New York: Routledge, 2007); Sukma, "Indonesia and The Challenge".

"Sukma, "Indonesia and the Challenge".

${ }^{10}$ Abdul Aziz, Aku Melawan Teroris! (Solo: Jazeera, 2004). 
to the condemnation of violence in the Quran. ${ }^{11}$

As terrorism and the movement of Al-Qaida's jihad has spread from the Middle east to Southeast Asia to Europe,${ }^{12}$ counter terrorism has also become a major concern in many countries in that region. In Indonesia particularly, after the Bali bombing, counter terrorism has become a main agenda for the government and the subject of research for many scholars. Hassan and Acharya agreed that understanding the perpetrators' thinking is important to counter their ideology and further to investigate the root of terrorism..$^{13}$ There is also the view that combating terrorism can be done by introducing Indonesian society to the legal consequences of terrorism as well as through education about the background, rationale and paradigm of terrorism. ${ }^{14}$ In addition, in relation to radical Islamism in Indonesia which is linked to Jemaah Islamiah (JI) and a product of foreign militancy, Barton has suggested that international cooperation should be run effectively to solve terrorism regionally and globally. ${ }^{15}$

Since the massive development of the internet, attention on terrorism issues and activism has emerged and is internationally discussed. Bunt argues that the 9/11 tragedy and Israeli-Palestinian conflict have gained international attention and become widely discussed in the online public sphere. Furthermore, online jihad activist or e-jihad groups have emerged with focused debate on conflicts in Chechnya, Palestine, Kashmir and Afghanistan, promoting their ideology and vision, as well as attracting both supporters and opponents. ${ }^{16}$ To disseminate their propaganda, the General Intelligence and Security Service (AIVD) of

${ }^{11}$ Hasan, "September 11"; Nasir Abas, Membongkar Jamaah Islamiyab: Pengakuan Mantan Anggota JI (Jakarta: Grafindo Khazanah Ilmu, 2005); Muhammad Haniff bin Hassan, Teroris Membajak Islam, Meluruskan Jihad Sesat Imam Samudra dan Kelompok Islam Radikal (Jakarta: Grafindo Khazanah Ilmu, 2007).

${ }^{12}$ Daniel Benjamin and Steven Simon, The Age of Sacred Terror (New York: Random House Audio, 2002).

${ }^{13}$ Muhammad Haniff bin Hassan, "Imam Samudra's Justification for Bali Bombing", Studies in Conflict \& Terrorism, vol. 30 (2007), pp. 1033-56; Arabinda Acharya, "The Bali Bombings: Impact on Indonesia and Southeast Asia", Islamism in Southeast Asia, Occasional Research Paper Series II, No. 2 (Centre for Eurasian Policy - Hudson Institute, 2006).

${ }^{14}$ Acharya, "The Bali Bombing".

${ }^{15}$ Fealy, Indonesia's Struggle.

${ }^{16}$ Gary R. Bunt, Islam in the Digital Age: E-Jihad, Online Fatwas and Cyber Islamic Environment (London: Pluto Press, 2003), p. 25. 


\section{Yuyun Sunesti}

the Netherlands reported that they have benefited from the development of the internet which has enabled them to find each other more quickly. ${ }^{17}$ AIVD mentioned that there are three models of jihadists spreading their ideology in the online public sphere which they differentiate as core and secondary forums, as well as surface web activity. Core forums refer to invisible webs where jihadists interact with other jihadists in a space which cannot be tracked. Here, the virtual gathering discusses various topics from a jihadist perspective, comment on their propaganda and materials, and come up with suggestions for further targets. ${ }^{18}$ The secondary forums function as a "bridge between core forums and the surface Webs". The jihadists of core forums redistribute propaganda from core forums to the visible surface webs such as facebook and youtube. ${ }^{19}$ In the invisible surface webs they spread jihadist ideas, recruit new jihadists, and promote their propaganda materials. Although the jihadists benefit from this online public sphere, AIVD argues that they are also afraid of being detected by government or intelligence so that the role of moderator or administrator of their visible webs is important to monitor and control web content. ${ }^{20}$

\section{Evidence from Online Discussion Forums}

In terms of terrorism issues, one of the debates confirms that the notion of martyrdom or heroism in terrorism discourse is being contested between different communities. Alexander gives an example of how the notion of salvation, holy war and sacred death are contested between East and West and how the social performances of one group are misperceived by another group. A recent example is the idea of martyrdom in Islam (jihad) which is perceived differently by followers of Islam and audiences and non-Islamic victims and audiences. For the former, jihad means "a sacred and highly demanding performance of holy war", in contrast, for the latter jihad is viewed as "an authentic demonstration of the polluted and demonic qualities of Islam itself". ${ }^{21}$ Similarly, the Gulf war is viewed

17 "Jihadism on the Web: A Breeding Ground for Jihad in the Modern Age", (AIVD Ministry of the Interior and Kingdom Relations of the Netherlands, 2009), https://www.aivd.nl/publish/pages/2402/samenvatting_ jihadistisch_internet_eng.pdf.

${ }^{18}$ Ibid., p. 6.

${ }^{19}$ Ibid., p. 7.

${ }^{20}$ Ibid., p. 8.

${ }^{21}$ Jeffrey C. Alexander, "From the Depths of Despair: Performance, Counterperformance and 'September 11", Sociological Theory, vol. 22, no. 1 
as a war of liberation by Westerners, but perceived as selfish, militaristic and orientalised by the Islamic community and humanitarian agencies. ${ }^{22}$ For Alexander, social performance as well as counter performances also occurred in the 2002 Bali bombing in which different perceptions about the perpetrators' actions were contested not only between Islamic and non-Islamic audiences, but also among Islamic audiences.

\section{The Secular Online Discussion Forums: Kompas and Detik}

In the period of July 2008 to January 2009, the discussion of the Bali bombing perpetrators became a popular topic discussed in most Indonesian online discussion forums. Themes ranged from the execution of the bombers, the terrorism phenomenon in Indonesia, as well as the debate on the bombers' claims of heroism.

It is reported that between July 2008 and January 2009 the most popular topic discussed in the Kompas and Detik forums was the execution of the perpetrators of the 2002 Bali bombing, with 19 and 11 topics respectively in which the members discussed about the pros and cons of the execution, the debate in defending Amrozi cs, the public responses to the execution and Amrozi and the fear of execution. It was followed by the debate around the phenomena after the execution (4 and 2 topics respectively) focusing on the debate on the pictures of the perpetrators' corpses, Amrozi's last statement and the responses of people in Amrozi;s hometown on his corpse, and then more general issues such as terrorist ideology and the phenomenon of terrorism in Indonesia with 8 topics in Kompas and 1 topic in Detik discussing the debate on jihad or terrorism, why people become terrorist as well as terrorism and foreign agents. .

Of the four themes, the debate on whether Amrozi cs should be executed was the themes most discussed, with 10 topics in Kompas and 5 in Detik forum, while the topic of Amrozi's fear of execution was discussed in the Kompas forum and not in Detik. The comment from Kompas member, very kaka (below), illustrates the pros of the execution that appeared in the forum:

I think I do agree if the terrorists are executed. They (Imam Samudera

cs) obviously confessed that they are the actors of the bombing. They

did not feel they are guilty at all for their killing of hundreds of innocent

people. They thought that people who do not agree with them are infidels

(2004), pp. 88-105.

${ }^{22}$ Ibid. 


\section{Yuyun Sunesti}

and must be banished from the earth. If they are like this, why should the Indonesian government consider their human rights, while on the other hand the terrorists killed the victims in inhuman ways for their fanaticism?...(very kaka, 3/11/2008) ${ }^{23}$

From the discussion, it is reported that the proponent of the execution of the Bali bombing perpetrators is higher than the opponent that is seen through the higher number of the frequency of theme supporting their execution. From 10 topics discussing the execution and 395 comments appeared in the Kompas discussion forum, there are 122 comments supporting the bombers' death penalty saying they deserve to die, because they kill hundreds people (13 comments) as well as their actions spoil Islam ( 7 comments). The other debate come up in this discussion is that they should be punished with other means such as life long jail term, executed by bombing (rajam) because these would inflict greater retribution and pain than the death penalty. Another comment is the support to execute the bombers' brainwasher as this party is more dangerous than the perpetrators (15 comments). A similar result is showed in the Detik forum with 13 comments appeared in supporting the execution (they deserve to die). The comment below confirms that the death penalty for the bombers should be enacted as it better equates with their actions:

I agree they should be executed by the death penalty. It is like amputating a part of patient's body to save him. The government should act seriously for legal supremacy. This execution is also important for their supporters to think twice in doing similar actions. If they are treated as celebrities, more people will want to do this. Now, it is proven that it is doubtful they will become martyrs. They look like they want to live. They seem to be victims brainwashing. (gwnzen 31/10/2008) ${ }^{24}$

In a different way, another member argued that rather than killing Amrozi cs, life sentences would be better to avoid the possibility that their supporters will perceiving them as martyrs:

in my opinion, they are guilty and must be punished...politically, perhaps death penalty is more 'deadly', but in my opinion, it is better to punish them with life in jail. This is because the death penalty will likely make them die like martyrs and encourage their supporters to die like them.

23 “Teroris Langsung Dihukum Mati, Gimana Komentar Anda?”, Forum Kompas.com (31 Oct 2008), http:/ / forum.kompas.com/nasional/8642-terorislangsung-dihukum-mati-gimana-komentar-anda.html, accessed 22 Oct 2009.

${ }^{24}$ Ibid. 
This can be seen from how many people are enthusiastic to welcome their corpses. This is dangerous because it can lead to an assumption that to die like the bombers is to die a hero. There is a willingness from many people for that. But, because the death penalty is a court decision, I just hope that the decision is right. But, remember that this punishment does not make their supporters fear or regret. This may even strengthen their motivation to die as in their mind it is martyrdom. (iRvZ 9/11/2008) $)^{25}$

Furthermore, the debate around their execution has also attracted the pros and cons of the execution. The arguments were they should not be executed (8 comments in kompas and 3 comments in Detik), death penalty should be banned for all crimes ( 4 comments in Kompas), they did it for a reason/ they defended Islam (4 in Kompas and 3 in Detik) and May God forgive them (9 in Kompas and 7 in Detik). They also argue that the execution will bring positive impacts such as the country will be safe (1 comment in Kompas), reduce the violence in the name of religion ( 3 comments in Kompas and 1 comment in Detik) and encourage more terrorism from Amrozi cs' supporters (3 in Kompas and 2 in Detik).

Interestingly, one of the debate on the execution is the members' questioning whether Amrozi cs were reasonably defended. This debate appeared since there were several events regarded by both forum members as implicitly and explicitly defending them. In the Kompas forum there were four events that provoked members to speak up. Firstly, the attempt of Tim Pembela Muslim (Team of Muslim Defenders) to abolish the death penalty. Secondly, the statement of Hidayat Nur Wahid, a former leader of Prosperous and Justice Party (PKS) and the chief of MPR at that time, saying that Amrozi cs were victims of the terrorism movement and the court should carefully and thoughtfully consider the appropriate punishment for them. The third defence came from Islamic Defenders Front (FPI) who threatened to come with hundreds followers to protest if the execution was held. The fourth was the defence from the leader of PKS, Tifatul Sembiring, who said that executing Amrozi should be chosen only after the government found proof of guilt, to avoid the circumstance where the government makes a mistake in executing people. From this debate, most members agreed that there was no basis for defending Amrozi. A similar result was also shown by the Detik Forum that debated the defence of Hidayat Nur Wahid. The following

25 "Pendapat Anda atas Eksekusi Amrozi CS", DetikForum (17 Dec 2014), http:/ / forum.detik.com/pendapat-anda-atas-eksekusi-amrozi-cs-t69320.html, accessed 23 Oct 2009. 


\section{Yuyun Sunesti}

comment argued that Amrozi should not be defended because the law had decided they were guilty:

There are many strange people in this country. Guilty people are defended.

The terrorists should be shot as soon as possible. There is already law proving they are guilty. The execution will end the debate and stop their statements which attracted many people to sympathize to them and regarded them as heroes. How come terrorists/killers are called as heroes, crazy! (ArdS 2/11/2008) ${ }^{26}$

Furthermore, discussion about Amrozi cs continued after their execution and the debate over their heroism started to heat up. Debates concerned with the pictures of the bodies of the perpetrators' and their last statements were popular on the Internet, as were the responses of citizens of Tenggulun, Amrozi's hometown. Only a few members said that the perpetrators' smiling faces were a sign of their martyrdom, while the majority argued that their smiling faces were the grimaces of people in pain:

the face of the martyr Imam Samudera shown by his family seemed bright and fresh, smiling, and face to the right side as an expression of their happiness and satisfaction to meet God. The martyr Imam Samudera went to God with a wound which becomes proof of martyrdom. (Badass77 $10 / 11 / 2008)^{27}$

Additionally, instead of debating in response to the corpses, a member in Kompas forum commented that photos of the perpetrators' circulated on the Internet had been edited by Photoshop and were far from original:

welcome to the propaganda...it is clearly made using Photoshop. This is made to show that they died smiling...like a hero. How can terrorists be seen as heroes...it is wrong... (Speedyrj 15/11/2008) ${ }^{28}$

Then, another debate after the execution was about the response of the people from Amrozi's hometown to his corpse. This discussion

26 “Ada juga yang Bela Teroris Loh...!", Forum Kompas.com (11 Feb 2008), http:/ / forum.kompas.com/ nasional/9014-warga-tenggulun-tolak-doakanamrozi-cs.html, accessed 22 Oct 2009.

27 "Foto Terakhir Imam Samudra Sebelum Dikebumikan", Detik.Forum, http: / / forum.detik.com/showthread.php?t=69411, accessed 23 Jan 2009.

28 "Foto Mayat Amrozi dan Mukhlas Beredar", Forum Kompas.com (15 Nov 2008), http:// forum.kompas.com/nasional/9595-foto-mayat-amrozidan-mukhlas-beredar.html, accessed 22 Oct 2009. 
appeared as a response to news in certain media that reported that the majority of the citizens of Tenggulun refused to pray for Amrozi. The following comment confirms this:

The people of Tenggulun are apparently smarter than Indonesian officials, some of whom 'softly' support Amrozi cs. Some said to respect the legal process, some said they are victims of terrorism...even the president of the PKS (Prosperous and Justice Party) said that if Amrozi cs are executed, the safety of the country will be in danger. In fact, the people of Tenggulun can differentiate between acts of terrorism and jihad. (Orangjelek 7/11/2008) $^{29}$

This statement supports the responses of the people of Tenggulun to Amrozi's corpse in comparison to those of some Indonesian officials who 'softly' defended Amrozi. According to one discussion forum member, locals of Tenggulun appeared smarter than the Indonesian officials who implicitly supported them.

The different perceptions of how people see Amrozi cs meant that people used different terms to refer to them. Members who were against their acts tended to describe them in negative terms, such as terrorist, killer, loser, while for members who supported their actions positive terms such as hero and martyr were used. From the discussion it was seen that most members in the Detik and Kompas Forums perceived and used negative terms to refer to Amrozi. The frequency of negative term come up in both forums were: word 'terrorist' emerged in Kompas Forum discussion 60 times and 13 times in Detik Forum, pembunuh (killer) 2 times both in Kompas and Detik, binatang (animal) once time in Kompas, Trio bomber (three bombers) 12 times in Kompas, pengecut (loser) 3 times in Kompas, and several calling come up one time in Detik called them as penjahat (criminal), elestrimis (extremist), pecundang (loser), sarap (crazy), cecunguk (blind follower), penyembah berbala (idol worshipper), penyembah setan (satanic worshipper) and badut (clown). On the other hand, there were only few people using positive terms. The word mujabid emerges one time in both Forums, pablawan (hero) three times in Detik forum and kambing hitam (scapegoat) once in Kompas. The comment below describes how the perpetrators were perceived as heroes. Some members of the Detik Forum said that the number of people who attended the bombers' funerals shows that there were many people who loved them:

29 "Warga Tenggulun Tolak Doakan Amrozi CS", Forum Kompas.com (15 Nov 2008), http:/ / forum.kompas.com/nasional/9014-warga-tenggulun-tolakdoakan-amrozi-cs.html, accessed 22 Oct 2009. 


\section{Yuyun Sunesti}

their funeral was attended by thousands of people sympathetic to them. They are acclaimed as heroes because they are truly heroes. (Grail $11 / 11 / 2008$ in Detik forum) $)^{30}$

Another member stated:

They are heroes for their supporters, but not for the Indonesian people. (Mbahnarjo 11/11/2008) ${ }^{31}$

On the other hand, many members who did not support their actions condemned them in negative terms:

Amrozi cs are fools and inhumane killers. They are not courageous people, but losers who are just brave to kill civilians who are not able to defend themselves. They are national traitors! How much suffering do they put on their own country? I am really happy these three clowns have been executed, a proper punishment for their sin and crime. Only fools who are sympathetic to them call them martyrs... DEATH TO TERRORISTS! LONG LIVE PANCASILA! LONG LIVE INDONESIA! FREE! (Ntut $11 / 11 / 2008)^{32}$

That most of the comments used negative terms in referring to the perpetrators' is understandable since Detik and Kompas forums are in the online public sphere which does not affiliate with any religious belief or institution. Therefore, the debate surrounding the perpetrators emphasises their violation of humanistic law, because they killed many people. Terms such as criminal, terrorist, killer, and crazy were often used to describe the perpetrators. There are also some members who called them mujahid and heroes, but this was not the mainstream view.

\section{Religious Online Discussion Forums: NU and Arrobmah}

The discussion about the Bali bombing tragedy had attracted NU Discussion Forum and Arrohmah Islamic Discussion Forum members to the online debate between July 2008 and January 2009. These debates mostly responded to the execution of the perpetrators especially the members' perception on whether they were reasonably executed. Terrorist ideology was another major focus topic.

The debate in the NU forum was concerned with how execution is viewed according to Islamic Sharia, the member's question on why God

30 "Amrozi CS Teroris Superstars?", DetikForum, http:// forum.detik. com/showthread.php?t=68771, accessed 23 Oct 2009.

${ }^{31}$ Ibid.

${ }^{32}$ Ibid. 
punishes Amrozi and when muslims witnessing crimes. Yet, support for Amrozi cs' actions became a popular topic in the Arrohmah forum under the discussion about the debate on the execution with 5 topics and one topic on an interview with the three Indonesian mujahid. The two comments below describe the sentiment of the NU forum:

From a legal perspective, their acts are not jihad, because jihad forbids killing children and women, but they did. Jihad is face-to-face fighting, not by hiding and then fighting weak people. Jihad is killing deviant people in a war, not killing non-Muslims who are not fighting Muslims. That is according to Islamic sharia (Afiqpradana 10/11/2008) 33 $^{33}$

If we ask Islamic leaders, they have different points of view. Radical Islamic leaders will say that the execution is a test for entering heaven due to being martyrs in establishing Islamic sharia. Liberal and moderate Islamic leaders will say based on Islamic doctrines that their punishment on earth is a punishment of their cruelty toward the innocent victims, children, women, civilians and etc in the name of religion. (Alatif $18 / 11 / 2008)^{34}$

In contrast, most of the Arrohmah forum members responded to Amrozi's execution in positive views by arguing that the execution of Amrozi cs leads them to be martyrs. One of the members even stated that they are the next generation of Amrozi cs' and will continue their actions.

We are here as supporters who continue what Amrozi cs' fought for...and for what they did to establish an Islamic state in Indonesia with Muslims as majority $(90 \%)$, but they proud of laws made by non-Muslims!! You cannot equalize the blood of Bali's victims with the blood of Muslim victims around the world. The blood of Muslim victims is more twice as valuable!! Even the blood of 202 Bali victims is not equal to that of those three martyrs (dr_daieyah 9/11/2008) ${ }^{35}$

Additionally, in discussing terrorist ideology, NU forum talk about what Muslim should do when seeing crime. As a counter to radical Muslims who act radically to anyone and any group who are claimed as doing opposing what Islamic doctrines said or deviate, mostly members in NU forum said that doing a radical act such as Amrozi's bombing is

33 "Hukuman Mati Amrozi dalam Syariat Islam", Forum Diskusi NU Online, http: / / forum.nu.or.id/viewtopic.php?f=4\&t=507\&hilit=amrozi, accessed 20 Dec 2009.

${ }^{34}$ Ibid.

35 "Haruskan Imam Samudra Dkk Dihukum Mati?", Arrahmah.com, http://www. arrahmah.com/index.php/forum/viewthread/819/, accessed 15 Feb 2009. 


\section{Yuyun Sunesti}

not what God orders.

...by giving an education and admonish them politely...that is enough... don't doing violence and destroy other people's property. Try follow Aa Gym's ways in combating gambling in Bandung... Violence isn't Islamic teaching, but Arabic Islmaic fanaticm, be careful! (Alatif 7/12/2008) ${ }^{36}$

On the other hand, from 5 topics and 59 comments on the debates about the execution, great support is shown by the Arrahmah forum members who see that the bombers' actions are purposeful - as fighting for injustice, apostasy (5 comments) and defending Muslims who are hurt by the West especially in conflict muslim countries such as Palestine and Afghanistan (4 comments) and they are executed without clear reason (1 comment). In contrast, from 3 topics and 33 comments about the execution, NU forum members mostly argued that jihad is not killing (6 comments), they killed hundreds including muslims (2 comments), they do not understand religious doctrines (3 comments) and they are wrong but may God forgive them (4 comments), while the comment about they fight for injustice and apostacy also existed with 2 comments.

Furthermore, as with the discussion in the Kompas and Detik forums in which the ways in which members refer to Amrozi cs depended on their views of them, this also appears the case in the NU and Arrohmah religious forums. Members who supported Amrozi cs tended to describe them in heroic terms --martyr (mujahid), fighter (pejuang), brother (saudara), as shown by most members in the Arrahmah forum. In contrast, members who were against their acts used negative terms --terrorist (teroris), criminal (penjahat) and prisoner (pesakitan).

The frequency of negative terms appear more often in NU forums, with four negative terms mentioned --teroris (terorist), mujabid yang salah arah (deviate mujahid), pesakitan (prisoner) and kelompok yang tak punya pegangan (confused group) and one positive term (korban konspirasi jabat (victim of wicked conspiracy). In contrast, 21 positive terms (mujabid (martyr--12 times), syahid (martyr), syuhada (martyr), pejuang (fighter--3 times), kekasih Allah (God's beloved), sahabat (friend), saudara (brother) and guru (teacher) and 2 negative terms (penjahat (criminal) and teroris (terrorist)) appear in the Arrahmah forum to describe the bombers. The following comments from members of the Arrohmah and NU forums illustrates how they described Amrozi cs:

36 "Ketika Melihat Kemunkaran", Forum Diskusi NU Online, http:/ / forum. nu.or.id/viewtopic.php?f=4\&t=507\&hilit=amrozi, accessed 20 Dec 2009. 
We just avoid all parties who support and executed the true mujahid... (ha4nadza 9/11/2008) ${ }^{37}$

Today, we are noiseless and falling silent with the killing by Jewish and Evangelist slaves upon our three friends, brothers and teachers: Imam Samudra, Amrozi and Ali Gufron (Calon Mujahid, 9/11/2008) 38 $^{38}$

While a member of the Arrohmah forum called these true mijabid, a member of the NU forum viewed them as people who have limited knowledge but who applied what they believe in their own way:

They are a confused group. They have no valid teachers and no connection to Imam Bukhari, Muslims, or Islamic schools. Their knowledge is not trusted and what they say is weak. They just follow doctrines with limited knowledge. This is what they do... (Afiqpradana 10/11/2008) ) $^{39}$

In comparison to the Kompas and Detik Forums which are more secular, the perpetrators are referred to using more using religious terms in the Arrahmah and NU forums. Although NU forum did not predominantly use strong religious terms as the Arrahmah forum members were inclined to do, religious terms were used in relation to the religious debate on the act. For example, the use of the expressions 'deviate mujahid' and 'confused group' by the forum members to describe the perpetrators, seen as obviously not basing their actions on Islamic values. While in Arrahmah, it was evident that religious terms were frequently used in reference to the perpetrators.

\section{The Bombers: Heroes or Anti-Heroes?}

The discussion about the 2002 Bali bombing reveals that there was significant attention given to the perpetrators of the Bali bombing. The data from the four Indonesian online discussion forums shows that besides condemnation of the bombers, praise was also given to them. These different views resulted in Amrozi cs being referred to in either negative or positive terms. The debate on the online forums centred around whether Amrozi cs were martyrs (heroes) or just criminals (antiheroes).

In understanding hero and anti-hero, Rollin suggests that a hero is "someone who has done something, something special, which others

37 "Bagaimana Sikap Terbaik Terhadap Eksekusi?”, arrabmah.com, http://www. arrahmah.com/index.php/forum/viewthread/854/, accessed 11 Feb 2009.

${ }^{38} \mathrm{Ibid}$.

39 "Hukuman Mati Amrozi". 


\section{Yuyun Sunesti}

feel has positive value and meaning". ${ }^{40}$ The image of heroes can be also viewed from two perspectives; internally, in which a hero is labelled due to an admiration of his/her artistic or intellectual achievements such as Einstein, Leonardo da Vinci and Shakespeare, and externally, in which a hero is associated with their struggle in winning in physical, intellectual or spiritual matters. ${ }^{41}$ As hero is identified with a struggle, he emphasized that "all heroes are 'born' (and sometimes die) amid tensions". "2 Furthermore, since heroes act based on some system of values --religious, moral, political--- or all three, rather than own interest, then the success of their actions is often used as a justification that what they and their community or religions believe is a right. ${ }^{43}$ On the contrary, Rollin defined anti-hero or villain as someone who acts for his/her private interest rather than for any value system. ${ }^{44}$

Similar to this heroic and anti-heroic frame, the nature of the contestation of the Bali bombers can also be seen in the differentiation made by other theorists, for example, Rollin's Hero-villain/anti-hero, Klapp's hero and villain, ${ }^{45}$ and Kooistra's heroic criminal, ${ }^{46}$ as well as Hobswam's social bandit. ${ }^{47}$ In these frames, the bombers have no inherent identity but can either be understood through either heroic or anti-heroic narratives, each distilling these figures with certain personal characteristics. Heroes are characterized as people who fight for a certain value system as well as defending the oppressed within their society from oppressors or powerful tyrants. Anti-heroes represent rebels who break the law to fulfil their purposes. However, in situations where there are tensions in society, the labels of hero and anti-hero cannot be given strictly to

${ }^{40}$ Roger B. Rollin, Hero/Anti-Hero (New York: McGraw-Hill Book, 1973), p. xv.

${ }^{41}$ Ibid.

${ }^{42}$ Ibid.

${ }^{43}$ Ibid.

${ }^{44}$ Ibid.

${ }^{45}$ Orrin Edgar Klapp, "Heroes, Villains and Fools, as Agents of Social Control”, American Sociological Review, vol. 19, no. 1 (1954), pp. 56-62, accessed 12 Jun 2009; Orrin Edgar Klapp, Heroes, Villains, and Fools: The Changing American Character (New Jersey: Prentice-Hall, 1962).

${ }^{46}$ Paul Kooistra, Criminals as Heroes: Structure, Power and Identity (Ohio: Bowling Green State University Popular Press, 1989).

${ }^{47}$ Eric John Hobsbawm, Primitive Rebels: Studies in Archaic Forms of Social Movement in the 19th and 20th Centuries, 3rd edition (Manchester: Manchester University Press, 1971). 
particular figures based on their actions, but rather are dependent on how different segments of society perceive them, either as heroes or villains. This is evident in the legend of Robin Hood, who was at the same time labelled hero and anti-hero.

Thus, viewing the Bali bombing phenomenon from a sociological perspective, contestation around the reputations of the perpetrators' represents a wider genre of conflict between martyrs and criminals. This two part differentiation is discussed by Rollin who said that this occurs because of the existence of more than one value system held by society. ${ }^{48}$ Those parts of society that agree with what the perpetrators did will see them as heroes, and on the contrary, by the part of society that condemns their actions they will be considered villains. The debate on the Bali bombers in the online forums therefore confirms the complex nature of Indonesian society in which there was no single opinion on the perpetrators' actions.

Of the four forums, Arrahmah was the only forum in which most members strongly admitted seeing Amrozi cs as heroes. They argued that what Amrozi cs did was a kind of martyrdom and that they died as martyrs. As Rollin said, a hero acts based on a certain value system. ${ }^{49}$ Most of the Arrahmah members believed that what Amrozi cs did was to fight against injustice and apostasy within society, as well as to defend Muslims around the world from Western cruelty. This belief held by supporters is confirmed in what Samudra said in his book where he argued that the 2002 Bali bombing was jihad against America and its allies as revenge for their cruelty in Afghanistan, Iraq and other Islamic countries. ${ }^{50}$ For this jihad, he stated that they were prepared for the death penalty, with eternal life as martyrs the reward. ${ }^{51}$ In fact, blaming the United States as a scapegoat for the destruction of Islamic values was a common value shared by the terrorists. Meister argued that there are several reasons why the United States is hated so much - the US supports reactionary regimes in order to get oil, 'Hollywood culture' portrayed on television promotes a nation of sex and violence, the US monopoly of economic power worldwide, and support for free trade and globalization. ${ }^{52}$ Globalization

${ }^{48}$ Rollin, Hero/ Anti-Hero.

${ }^{49}$ Ibid.

${ }^{50}$ Aziz, Aku Melawan Teroris!.

${ }^{51}$ Ibid.

${ }^{52}$ Charles W. Meister, From Terrorism to World Peace (USA: New Falcon Publications, 2002), pp. 8-9. 


\section{Yuyun Sunesti}

and the increased Westernization of Islamic countries has been claimed to have triggered Islamic conservative group members, such as the bombing perpetrators, to react and fight against the new values that they perceive to be a threat to their values. Bali is seen to represent all the symbols of globalization and westernization and as a result these introduced cultural changes must be eliminated in Indonesia as a symbol of the ideological war against America and its allies.

There were NU forum members, however, who emphasized that martyrdom and being martyrs cannot be gained through the bombings and that Amrozi cs' were mistaken in their understanding of religious doctrines. These posts by NU members refer to the bombers as 'deviate mujahid' (mujabid yang salah arah) and 'confused group' (kelompok yang tak punya pegangan). Similarly, the online members of Kompas and Detik forums also mostly cursed what Amrozi cs did and called them killers and criminals. They questioned the values the bombers used to justify their actions, such as defending Islam and fighting against injustices within Indonesian society. Many Kompas and Detik forums members believed that rather than fighting for values, they were just uneducated poor people who were victims of brainwashing and blind fanaticism.

Another issue that came up in the discussion was the opinion of a chief of the MPR (Majelis Permusyawaratan Rakyat/People's Consultative Council) at that time, Hidayat Nur Wahid, who it was claimed gave implicit support to the bombers. This split in opinion among the elite was also regarded as having significant effect in forming the opinions of the people at the grass roots of Indonesian society. Further, the perpetrators and their execution were intensively publicized on television and in other media. ${ }^{53}$ The long delay of their execution also resulted in the public questioning whether the government would uphold the law.

In sum, the debate on the heroism of the bombing perpetrators depends on what society will agree or not agree upon in relation to the perpetrators perceived beliefs and actions. The contestation of the status of hero and anti-hero also has the function of becoming a collective symbol, ${ }^{54}$ or issue generating public solidarity ${ }^{55}$ through which various groups organize and struggle for control in their attempts to represent and articulate what their group's beliefs are and who they support. For the supporters of Amrozi, he is collective symbol of their fight against

53 "Seolah-olah Pahlawan", TEMPO (30 Dec 2008).

${ }^{54}$ Klapp, "Heroes, Villains and Fools".

${ }^{55}$ Rollin, Hero/Anti-Hero. 
the domination of global Western power and the hegemony of Western values around the world, especially in Islamic countries, as well as a symbol of a return to 'original' Islamic values. As anti-hero, he is a collective symbol for another segment of Indonesian society which is against terrorism, supports tolerance and diversity, and upholds world peace.

\section{E. Construction of Discourse and the New Public Sphere}

In discussing the issue of terrorism in Indonesia, the four online discussion forums each have different concerns and characteristics in terms of what is narrated, described and discussed in their textual debates. These differences appear in the form of discourse construction - in how and what language is used, as well as the characteristics of the flow of the debate. In the discourse construction frame, analysis focuses on the establishment of heroes/anti-heroes and the dominant discourses implied in each forum. Furthermore, as the forums each had members from different backgrounds the languages they used were also relatively different. The different nature of the debate from forum to forum also shows how this new public sphere works in transferring information and beliefs among members.

The establishment of the figures of the bombers as heroes and anti-heroes within the forums was one discourse constructed by members to create an agreement among members. From this, it can be argued that the debate in the two more secular forums, Detik and Kompas, tended to establish an anti-heroic discourse among members based on the discussion which was mostly against what Amrozi cs did. The antihero status is articulated through description of the bombers as cruel, inhuman and full of hatred. The depiction of Amrozi cs as heroes was not a popular discourse in these forums with very few members in support. Similarly, the discussion in the NU forum also revealed the anti-hero discourse for the bombers by characterizing them from the Islamic legal view, as people who God will punish on earth with execution. In contrast, the hero discourse is strongly established in the Arrohmah forums in which the members portray the bombers as fighters, and as faithful and brave, while Westerners, especially from America, which is described as an oppressor, infidel and cruel, and the Indonesian government who they consider tyrannical due to the execution of Amrozi cs are portrayed to be anti-heroes.

In addition, the new public sphere reveals the dominant discourses 


\section{Yuyun Sunesti}

discussed by the groups within Indonesian society in response to the bombers' execution. Based on the topics discussed, the two secular forums tended to look at the execution from the perspectives of the perpetrators' crimes and punishment versus supremacy of the law and the government's willingness to execute them. The discussion in the NU forum implied the tension in contesting Islamic moderate values and fundamentalist-radical values by debating several issues related to Islamic doctrine, while the Arrohmah forum tended to position Islam vis-a- vis the West, as enemy, and Amrozi cs' jihad versus the tyrannical Indonesian government.

These dominant discourses are also strengthened by the languages used by the members. In describing the topics for example, the members in the Kompas forum used titles which clearly condemned terrorism, such as "is it reasonable to defend terrorists?", "Finally, violence and terrorism are conquered!" and "congratulations! Densus 88 succeeded in arresting terrorists again". Even though not as strong in showing the opposition to terrorism as Kompas, the topic titles in the Detik forum also implied that most were against the bombers but used the form of questioning language, such as "Do you believe Amrozi cs are the Bali bombers?", "your opinions about the Amrozi cs' execution" and "Amrozi cs are superstars?". On the other hand, the use of language by Arrahmah forum members was somewhat 'flaming up' in support of jihad. The topic titles used were also obviously in support of the bombers' actions, such as "an interview with the three Indonesian martyrs" and "Just before Amrozi's martyrdom". In a different way, the content in the NU Forum was mostly on Islamic themes, including daily devotion and debate on jihad. In responding to the Bali bombers' execution, the debate that appeared in the forum was about execution in Islamic law. The members tended to discuss what Amrozi cs did from an Islamic legal point of view and supported their opinions with the Quran and hadith. The topic titles also show this debate, such as "Amrozi's death penalty in Islamic Sharia" and "Why does God punish Amrozi?"

Furthermore, as a new public sphere, these online discussion forums facilitate the debate among members that is easy to access, fast and more equal among them. This is proven by the ease with which online users can register and comment, as well as criticize the opinions of other members. Looking at the four online forums, it can be argued that the two secular forums and the NU forum are closer to the characteristics in which the discussion within the forums is viewed as more flowing, 
as every member can participate without control or intimidation from the other members or even a moderator. However, this characteristic is rare in Arrohmah forums, in which the discussion is dominated by particular views, in this case supporting Amrozi cs, and by members who tended to force their views onto members with different opinions. The administrators also play a significant role in this indoctrination. This can be seen from their intensive work to post news, give opinions and even criticize members who try to give different opinions. The comment below from the administrator is an example response to a member (with the name KASIH) who agrees with the execution of the perpetrators:

KASIH you must be KUFFAR, MURTADDIN, Munafiqun, or Fasiqun...

Please choose one of them....If you are a part of them, you should not be in this forum...please clarify! (Administrator, 22/01/2009). ${ }^{56}$

Imam must be executed because he killed many people and because our country has a law (KASIH, 09/11/2008). ${ }^{57}$

From this, as Barton said, the online discussion forum has similar characteristics to Habermas' coffee shops in eighteenth century in which everyone can participate and disregard the status of the patrons / users. ${ }^{58}$ Three of the online discussion forums meet this criteria, while the Arrahmah forum tends to limit its forum membership to members who have similar views with them as shown by the many suggestions from members to close the accounts of members who post different opinions. Because of this, the debate in the forum represents the dominant discourse that exists under the control of the moderator and through which there is little chance for the members to change their opinions. In addition, even though they are more open and are less controlled by the moderator, the discussion in the other three forums also shows similarly that the majority view tends to allow the dominant discourse to run in the forums.

\section{F. Concluding Remarks}

This research on online forums relating to the 2002 Bali bombing and the idea of heroism of the perpetrators' has found three general arguments: firstly, that the existence of support for terrorism in Indonesia

56 "Haruskan Imam Samudra".

${ }^{57} \mathrm{Ibid}$.

${ }^{58}$ Matthew D. Barton, "The Future of Rational-Critical Debate in Online Public Spheres”, Computers and Composition, vol. 22, no. 2 (2005), p. 179. Al-Jämi‘ah, Vol. 52, No. 1, 2014 M/1435 H 
and Islamic nations represented in online discussion forums confirms, but also challenges, the beliefs and fears in the West about the threat of terrorism around the world. Another finding is that the contestation of the notion of heroism and the emergence of the portrayal of the perpetrators as heroic or criminal is also argued as not a new form of pathological mythologising but one which has firm roots in established global heroic and anti-heroic frames. Finally, it has been argued that even though the online forum is a relatively new public sphere that ensures the members have access to open, equal and critical discussion, the hegemonic discourses still remain within the discussion groups since the debates in the forums tends to be dominated by certain views.

In brief, as one form of communication media, although it cannot represent what most Indonesian people thought about terrorism and the 2002 Bali bombing, online forums give a description in specific ways as to what Indonesian people thought and how they perceived that issue. The different ways that the members discussed certain issues in the forum can also be used to look at Habermas' idea of the public sphere which is open and equal discussion among members, in the contemporary public sphere of the internet. It is hoped this study will be useful in starting a discussion to further investigate the issue of terrorism in Indonesia, as well as to confirming the importance of cultural research on the hero and anti-hero. 


\section{BIBLIOGRAPHY}

Abas, Nasir, Membongkar Jamaah Islamiyah: Pengakuan Mantan Anggota JI, Jakarta: Grafindo Khazanah Ilmu, 2005.

Abuza, Zachary, Political Islam and Violence in Indonesia, New York: Routledge, 2007.

Acharya, Arabinda, "The Bali Bombings: Impact on Indonesia and Southeast Asia", Islamism in Southeast Asia, Occasional Research Paper Series II, no. 2, Centre for Eurasian Policy - Hudson Institute, 2006.

“Ada Juga Yang Bela Teroris Loh...!", Forum Kompas.com, 11 Feb 2008, http://forum.kompas.com/nasional/9014-warga-tenggulun-tolakdoakan-amrozi-cs.html, accessed 22 Oct 2009.

Alexander, Jeffrey C., "From the Depths of Despair: Performance, Counterperformance and 'September 11', Sociological Theory, vol. 22, no. 1, 2004, pp. 88-105 [doi: 10.1111/j.1467-9558.2004.00205.x].

“Amrozi CS Teroris Superstars?”, DetikForum, http:/ / forum.detik.com/ showthread.php?t=68771, accessed 23 Oct 2009.

Asfar, Muhammad (ed.), Islam Lunak Islam Radikal: Pesantren, Terrorisme Dan Bom Bali, Surabaya: PuSDeHAM dan JP Press, 2003.

Aziz, Abdul, Aku Melawan Teroris!, Solo: Jazeera, 2004.

Azra, Azyumardi, "Bali and Southeast Asian Islam: Debunking the Myths", in After Bali: The Threat of Terrorism in Southeast Asia, ed. by Kumar Ramakrishna and Seng Seng Tan, Singapore: Institute of Defence and Strategic Studies Nanyang Technological University and World Scientific Publishing Company, 2003.

"Bagaimana Sikap Terbaik Terhadap Eksekusi?", arrahmah.com, http:// www.arrahmah.com/index.php/forum/viewthread/854/, accessed 11 Feb 2009.

Barton, Matthew D., "The Future of Rational-Critical Debate in Online Public Spheres", Computers and Composition, vol. 22, no. 2, 2005, pp. 177-90.

Benjamin, Daniel and Steven Simon, The Age of Sacred Terror, New York: Random House Audio, 2002.

Bunt, Gary R., Islam in the Digital Age: E-Jihad, Online Fatwas and Cyber Islamic Environment, London: Pluto Press, 2003.

Fealy, Greg, Indonesia's Struggle: Jemaah Islamiyah and the Soul of Islam, Sydney: 
Yuyun Sunesti

UNSW Press, 2004.

"Foto Mayat Amrozi dan Mukhlas Beredar", Forum Kompas.com, 15 Nov 2008, http:/ / forum.kompas.com/nasional/9595-foto-mayatamrozi-dan-mukhlas-beredar.html, accessed 22 Oct 2009.

"Foto Terakhir Imam Samudra Sebelum Dikebumikan", DetikForum, http:/ / forum.detik.com/showthread.php?t=69411, accessed 23 Jan 2009.

"Haruskan Imam Samudra dkk Dihukum Mati?”, arrahmah.com, http:/ / www.arrahmah.com/index.php/forum/viewthread/819/, accessed 15 Feb 2009.

Hasan, Noorhaidi, "September 11 and Islamic Militancy in Post-New Order Indonesia", in Islam in Southeast Asia: Political, Social and Strategic Challenges for the 21st Century, ed. by K.S. Nathan and Mohammad Hashim Kamali, Singapore: Institute of Southeast Asian Studies, 2005.

Hassan, Muhammad Haniff bin, Teroris Membajak Islam, Meluruskan Jihad Sesat Imam Samudra Dan Kelompok Islam Radikal, Jakarta: Grafindo Khazanah Ilmu, 2007.

----, 'Imam Samudra's Justification for Bali Bombing", Studies in Conflict \& Terrorism, vol. 30, 2007, pp. 1033-56.

Hobsbawm, Eric John, Primitive Rebels: Studies in Archaic Forms of Social Movement in the 19th and 20th Centuries, 3rd edition, Manchester: Manchester University Press, 1971.

"Hukuman Mati Amrozi dalam Syariat Islam", Forum Diskusi NU Online, http:/ / forum.nu.or.id/viewtopic.php?f=4\&t=507\&hilit=amrozi, accessed 20 Dec 2009.

"Jihadism on the Web: A Breeding Ground for Jihad in the Modern Age", AIVD Ministry of the Interior and Kingdom Relations of the Netherlands, 2009, https://www.aivd.nl/publish/pages/2402/ samenvatting_jihadistisch_internet_eng.pdf, accessed 19 Mar 2014.

"Ketika Melihat Kemunkaran”, Forum Diskusi NU Online, http: / / forum. nu.or.id/viewtopic.php?f $=4 \& \mathrm{t}=507 \&$ hilit $=$ amrozi, accessed 20 Dec 2009.

Klapp, Orrin Edgar, "Heroes, Villains and Fools, As Agents of Social Control", American Sociological Review, vol. 19, no. 1, 1954, pp. 56-62 [doi: 10.2307/2088173]. 
The 2002 Bali Bombing and the New Public Sphere

Kooistra, Paul, Criminals as Heroes: Structure, Power and Identity, Ohio: Bowling Green State University Popular Press, 1989.

Lutz, James M. and Brenda J. Lutz, Global Terrorism, New York: Routledge, 2004.

Meister, Charles W., From Terrorism to World Peace, USA: New Falcon Publications, 2002.

Pape, Robert Anthony, Dying to Win: The Strategic Logic of Suicide Terrorism, New York: Random House, 2005.

"Pendapat Anda atas Eksekusi Amrozi CS", DetikForum, 17 Dec 2014, http:// forum.detik.com/pendapat-anda-atas-eksekusi-amrozics-t69320.html, accessed 23 Oct 2009.

Rollin, Roger B., Hero/Anti-Hero, New York: McGraw-Hill Book, 1973.

Sukma, Rizal, "Indonesia and The Challenge of Radical Islam After 12 October", in After Bali: The Threat of Terrorism in Southeast Asia, Singapore: Institute of Defence and Strategic Studies Nanyang Technological University and World Scientific Publishing Company, 2003.

“Seolah-olah Pahlawan”, TEMPO, 30 Dec 2008.

“Teroris Langsung Dihukum Mati, Gimana Komentar Anda?”, Forum Kompas.com, 31 Oct 2008, http:// forum.kompas.com/ nasional/8642-teroris-langsung-dihukum-mati-gimana-komentaranda.html, accessed 22 Oct 2009.

"Warga Tenggulun Tolak Doakan Amrozi CS", Forum Kompas.com, $15 \mathrm{Nov}$ 2008, http:// forum.kompas.com/nasional/9014-warga-tengguluntolak-doakan-amrozi-cs.html, accessed 22 Oct 2009.

Yunanto, S., Militant Islamic Movements in Indonesia and South-East Asia, Jakarta: Friedrich Ebert Stiftung: Ridep Institute, 2003. 